\title{
Perspectives of the Euro Area Sovereign Debt Crisis for the Brazilian Economy
}

Horst Dieter Moller*

Tales Vital**

\begin{abstract}
The objective of this article is to show the perspectives of the euro area sovereign debt crisis for the Brazilian economy. The euro area sovereign debt crisis, beginning in 2010, could be seen as fallout of the global financial crisis of 2008/09. The ways to the crisis for Portugal, Ireland, Italy, Greece and Spain were different: Credit booms and housing bubbles, banking crises, unsustainable public indebting. The impacts on Brazil were felt in 2011 and 2012 with the Brazilian economy almost stagnating. The article evaluates the impacts of the global financial crisis 2008/09 on the Brazilian economy through real and monetary channels, as well as through the contagion of expectations, to find similarities with the present crisis. The main influence was the fall of Brazilian exportations and the credit crunch following the failure of Lehman Brothers in September 2008. The article supposes that the impacts of the euro area crisis shall be less problematic than that of the global financial crisis of 2008/09, because exportations are geographically more diversified and a credit crunch could be confronted by the BNDES and the public banks in Brazil. But the main argument is that the stability of Brazilian institutions, the geographical diversification of exportations and the increasing demand for commodities by the emerging markets in Asia will soften the impacts of the present crisis for Brazil, supposing that contagion of the sovereign debt crisis in the euro area will not expressively hit the more important economic powers in Europe and the world. The causes of the stagnating Brazilian economy in 2012 probably are not only the problems in the euro area.
\end{abstract}

Keywords: Financial crises. Brazilian economy. Contagion of crises.

Resumo: O artigo mostra as perspectivas da crise da dívida soberana na área do euro a partir de 2010 para a economia brasileira, que pode ser visto como um impacto defasado da crise financeira global de 2008/09. Os países atingidos, Portugal, Irlanda, Itália, Grécia, Espanha, tinham caminhos diferentes para a crise: booms de

\footnotetext{
* Doutor em Economia pela Universidade de Hamburgo (Alemanha). Professor no Programa de Pós-Graduação em Administração e Desenvolvimento Rural da Universidade Federal Rural de Pernambuco (UFRPE).E-mail: horstdm@hotmail.com

* $\quad$ Doutor em Economia pela Universidade Federal de Pernambuco (UFPE). Professor no Programa de Pós-Graduação em Administração e Desenvolvimento Rural da Universidade Federal Rural de Pernambuco (UFRPE). E-mail: talesvital@hotmail.com
} 
crédito e bolhas no mercado imobiliário, crises bancárias ou uma dívida pública insustentável. Os impactos sobre o Brasil foram sentidos em 2011 e 2012 com a quase estagnação da economia brasileira. $\mathrm{O}$ artigo avalia o contágio da crise financeira global de 2008/09 para o Brasil considerando os canais reais e monetários de transmissão, bem como o contágio através das expectativas, para encontrar semelhanças com a crise atual. O impacto principal da crise global foi a queda das exportações brasileiras e a crise do crédito após a falência do Lehman Brothers em setembro de 2008. O artigo mostra que os impactos da crise na área do euro para o Brasil serão menos problemáticos do que os impactos da crise financeira global de 2008/09, porque as exportações estão geograficamente mais diversificadas e a crise de falta de crédito no setor privado pode ser contornada pela concessão de crédito através do BNDES e dos bancos públicos. Mas o principal argumento baseia-se na estabilidade das instituições brasileiras, na diversificação geográfica das exportações e na crescente demanda por commodities por parte dos mercados emergentes da Ásia que vão amenizar os impactos da crise atual para o Brasil, admitindo que essa crise na área do euro não aprofunde seus efeitos negativos para os países economicamente mais importantes na Europa e no mundo. As causas da economia brasileira quase estagnada em 2012, provavelmente, não são apenas os problemas na zona do euro.

Palavras-chave: Crises financeiras. Economia brasileira. Contágio das crises.

JEL Classification: E32; E 39; F44.

\section{Introduction}

The euro area sovereign debt crisis could be seen as fallout of the global financial crisis of 2008/09 and the following global recession (some authors call it the Great Recession) for countries in the euro area that suffered non sustainable credit booms and housing bubbles accompanied by banking crises when the boom crashed (Ireland and Spain) and entered in massive fiscal deficits by saving the financial system and avoiding deeper recessions by expansionary monetary and fiscal politics. Other countries had high public debts like Italy or were indebting rapidly in the time of easy and cheap credit like Greece or were rapidly indebting in times of the global financial crisis like Portugal. In the spring of 2010 investors awakened realizing that the public indebting of these countries (Portugal, Italy, Ireland, Greece, Spain) was unsustainable. Selling sovereign debt of these countries made the yield of sovereign bonds sore making borrowing costs for some countries unsustainable when rolling over maturing debt. At this times concerns over the interaction of the sovereign debt problems and vulnerabilities in the euro area banking sector rose, because many European banks were heavily invested in sovereign bonds of 
these countries. Assistance programs in 2010 for Greece, Portugal and Ireland of de European Union (the current European Financial Stability Facility (EFSF) will be replaced by the European Stability Mechanism (ESM) in June 2013) seemed a relief for a time, but accompanied by measures of fiscal austerity, led some countries to recession and even deeper fiscal problems. In October 2011 contagion reached the third- and fourth-largest economies in the euro area Italy and Spain. The European Central Bank (ECB) intervened in secondary sovereign bond markets buying sovereign debt to lower yields. In early 2012 a negotiated default on sovereign debt of Greece led to predicable losses of $80 \%$ of owners of those bonds in the private sector, while the official hair-cut is only 50\%. In September 2012 the European Central Bank (ECB) introduced the Outright Monetary Transactions (EUROPEAN CENTRAL BANK, 2012) (OMTs) facilitating the buying of short term sovereign debt (maturity between one and three years) without specified limits to bring down yields on sovereign debt.

The crisis in the euro area shows the problems of the monetary unit of the euro area, the euro. The euro since its creation in 1999 has been a political project, unifying more firmly today 17 countries of the European Union (EU 27 member states). Its main shortcoming is that the euro is money without a state, without a unified fiscal policy and fiscal control. The economic development in the euro area since the global financial crisis and before didn't lead to convergence in economic and social conditions of the member states, but especially in fiscal deficit, public debt, current transactions and yet more important in competitiveness to divergence in some countries, especially in the south of the euro area. This differences in competitiveness in the euro area now cannot be solved by adjustment of the exchange-rate (devaluing) or expansionary monetary policies, because the euro exists for all countries within the euro area and the monetary policy is also unified by the ECB. Differences in competitiveness can only be solved by deflationary policies in countries that lack competitiveness, by migration or expressive productivity growth. These distressful and slow solutions lead to social unrest and conflicts as the return of the United Kingdom to the overvalued prewar exchange-rate of the pound to the US Dollar in 1925 has shown.

This article tries to show the possible fallout of the euro area sovereign debt crisis for the Brazilian economy, considering the transmission of crisis effects to Brazil through real and monetary channels and the contagion of expectations. The importance of this article lies in the possibility of quantifying macroeconomic impacts on the Brazilian economy in future crises. The first topic after this introduction shows a short description of the global financial crises 2008/09 and focuses on the present euro area sovereign debt crises and its impacts on the global economy. The second topic focuses on the real effects especially for Brazilian exportations and transferences of income to and from Brazil. The third topic focuses on contagion 
of expectations and the fourth topic on transmission of the crisis through monetary channels. The fifth topic resumes the effects trying to make previsions for the Brazilian economy considering all channels of transmission of the crisis including the political transmission channel which focuses on the attempt of countries to follow policies of protectionism in the time of international crises. The conclusions terminate the article.

\section{The Euro Area Sovereign Debt Crisis as Fallout of the Global Financial Crisis 2008/09}

The euro area sovereign debt crisis could be interpreted as fallout of the global financial crisis 2008/09, but there are also specific causes in the recent economic history and in economic structures of the involved countries Portugal, Ireland, Italy, Greece and Spain and possibly Belgium. These specific causes are related later on in this topic.

In 2007 first signals of a crisis were felt in the United States in housing markets, credit markets and securitized mortgage bonds markets, and partially in some banks in Europe (BNP Paribas, France; Industriekreditbank IKB, Germany), which were heavily invested in these securitized bonds, partially through Special Investment Vehicles (SIV). The crisis turned definitely global in September 2008 with the failure of the investment bank Lehman Brothers and the impending collapse of the insurance giant American International Group (AIG) (THE FINANCIAL CRISIS INQUIRY COMMISSION, 2011, p. XVI). Financial markets all over the world panicked, liquidity in the interbank money markets vanished and interest rates soared, stock-markets plummeted and many countries of the world went into deep recession.

President Obama resumed in preface of the Economic Report of the President 2012 some of the causes and the problems arising from the global financial crisis

In 2008, the house of cards collapsed. We learned that mortgages had been sold to people who could not afford them or did not understand them. Banks had made huge bets and doled out big bonuses with other people's money. Regulators had looked the other way, or did not have the authority to stop the bad behavior. It was wrong. It was irresponsible. And it plunged our economy into a crisis that put millions out of work, saddled us with more debt, and left innocent, hardworking Americans holding the bag. (UNITED STATES GOVERNEMENT, 2012, p. 2).

The causes of the Great Recession, how the Bank of International Settlements (BIS) called the fallout of global financial crisis (BIS, 2011, p. 10) are still in discus- 
sion between economists, focusing on failures of the government and the Central Banks or focusing on failures of the markets.

Failures of the Governments and the Central Banks, not only in the United States, were the excessively expansive monetary policies since the crash of the stock market of new technologies in 2000/01 resulting in credit booms and a bubble in the housing market (THE FINANCIAL CRISIS INQUIRY COMMISSION, 2011 , p. XVI) and the failure to regulate the excessive risk taking and leveraging of the banking system and the shadow banking system and control the expansion of new financial instruments in the securities and derivative markets (Mortgage Backed Assets MBAs, Collateralized Debt Obligations CDOs, Credit Default Swaps CDS).

Failures of the markets were excessive risk taking and leveraging by the financial institutions lead by wrong incentives (compensation structures) on short term profits. Financial institutions knowing that in the in case of problems they would be bailed out by government and the Central Bank, because they too big to fail, took on practices of excessive risk taking and practices of predatory lending. Failures of the markets also were financial innovations, like new financial instruments: collateralized debt obligations (CDOs) and credit default swaps (CDS) which created unknown risks leading to mortgage lending without risk assessment of the debtor and partially to predatory lending, and the failure of the rating agencies to assess properly the risk of securitized mortgages, led by wrong incentives. The securitization of mortgages led the banks to neglect a proper risk assessment of debtors, because the mortgages left the balance sheets of the banks after securitization. The problem of moral hazard and thus excessive risk taking created by regulators and government by insuring financial institutions, "too big to fail", to bail them out in case of failure could be seen as a general problem of the financial system (ROUBINI; MIHM, 2010)] and as a form of socializing losses of the private sector. The Minsky hypothesis (MINSKY, 2008, p. 230) of the inherent instability of the financial system in a capitalist economy created by excessive credit expansion in the boom and the retraction of credit in the following crisis could be seen as a generalization of the problems of failure of the markets also leading to open fraud as the PONZI-scheme of Madoff and others.

The consequences for the global financial crisis for growth, trade and gross public debt for the most important economies of the world and Brazil are shown in Table 1, showing expressive fall in trade for all countries reported and deep recessions in all countries reported other than China, which had a light fall in growth rate in 2009 and Brazil where the recession was light and short. 
Table 1 - Macroeconomic perspectives United States, China, Japan, Germany and Brazil 1980-2012

\begin{tabular}{|c|c|c|c|c|c|c|c|c|}
\hline & $\begin{array}{l}1980- \\
1989 \\
\end{array}$ & $\begin{array}{l}1990- \\
1999 \\
\end{array}$ & $\begin{array}{r}2000- \\
2007 \\
\end{array}$ & 2008 & 2009 & 2010 & 2011 & $2012^{1}$ \\
\hline \multicolumn{9}{|c|}{ United States of America } \\
\hline Anual growth rate of real GDP (\%) & 3,0 & 3,2 & 4,3 & $-0,3$ & $-3,5$ & 3,0 & 1,7 & 2,0 \\
\hline $\begin{array}{c}\text { Anual growth rate of real } \\
\text { importations (\%) }\end{array}$ & 5,6 & 9,2 & 13,0 & $-3,8$ & $-15,6$ & 14,8 & 5,7 & 3,0 \\
\hline $\begin{array}{c}\text { Anual growth rate of real } \\
\text { exportations (\%) }\end{array}$ & 5,4 & 7,6 & 9,9 & 6,3 & $-12,0$ & 14,4 & 7,4 & 4,2 \\
\hline Current Account/GDP (\%) & $-1,7$ & $-1,6$ & $-4,9$ & $-4,7$ & $-2,7$ & $-3,2$ & $-3,1$ & $-3,3$ \\
\hline Gross Public Debt/GDP (\%) & 53,0 & 68,2 & 62,1 & 76,1 & 89,9 & 98,5 & 102,9 & 106,6 \\
\hline \multicolumn{9}{|c|}{ China } \\
\hline Anual growth rate of real GDP (\%) & 9,7 & 10,0 & 13,2 & 9,6 & 9,2 & 10,4 & 9,2 & 8,0 \\
\hline $\begin{array}{c}\text { Anual growth rate of real } \\
\text { importations (\%) }\end{array}$ & 9,5 & 12,9 & 22,8 & 3,4 & 2,5 & 22,3 & 9,7 & 10,1 \\
\hline $\begin{array}{c}\text { Anual growth rate of real } \\
\text { exportations (\%) }\end{array}$ & 8,4 & 15,7 & 23,8 & 8,2 & $-10,7$ & 28,4 & 9,4 & 6,7 \\
\hline Current Account/GDP (\%) & $-0,3$ & 1,7 & 4,6 & 9,1 & 5,2 & 5,1 & 2,8 & 2,3 \\
\hline Gross Public Debt/GDP (\%) & 3,7 & 7,7 & 18,0 & 17,0 & 17,7 & 33,5 & 25,8 & 22,0 \\
\hline \multicolumn{9}{|c|}{ Japan } \\
\hline Anual growth rate of real GDP (\%) & 4,4 & 1,5 & 1,4 & $-1,0$ & $-5,5$ & 4,4 & $-0,7$ & 2,4 \\
\hline $\begin{array}{l}\text { Anual growth rate of real } \\
\text { importations (\%) }\end{array}$ & 3,4 & 6,6 & 9,1 & 0,1 & $-16,0$ & 15,3 & 5,8 & 2,4 \\
\hline $\begin{array}{c}\text { Anual growth rate of real } \\
\text { exportations (\%) }\end{array}$ & 5,1 & 3,4 & 4,8 & $-1,3$ & $-27,6$ & 25,4 & $-2,1$ & 2,3 \\
\hline Current Account/GDP (\%) & 2,0 & 2,3 & 3,3 & 3,2 & 2,8 & 3,6 & 2,0 & 2,2 \\
\hline Gross Public Debt/GDP (\%) & 64,3 & 91,1 & 170,4 & 191,8 & 210,2 & 215,3 & 229,8 & 235,8 \\
\hline \multicolumn{9}{|c|}{ Germany } \\
\hline Anual growth rate of real GDP (\%) & 1,9 & 2,1 & 2,4 & 0,8 & $-5,1$ & 3,6 & 3,1 & 1,0 \\
\hline $\begin{array}{c}\text { Anual growth rate of real } \\
\text { importations (\%) }\end{array}$ & 3,8 & 5,8 & 7,2 & 3,7 & $-9,8$ & 12,8 & 8,8 & 1,9 \\
\hline $\begin{array}{c}\text { Anual growth rate of real } \\
\text { exportations (\%) }\end{array}$ & 4,9 & 5,0 & 7,0 & 2,3 & $-16,3$ & 15,2 & 9,1 & 1,7 \\
\hline Current Account/GDP (\%) & 2,0 & $-0,6$ & 3,2 & 6,2 & 5,9 & 6,1 & 5,7 & 5,2 \\
\hline Gross Public Debt/GDP (\%) & n.a. & 52,3 & 64,0 & 66,7 & 74,4 & 83,2 & 81,5 & 78,9 \\
\hline \multicolumn{9}{|c|}{ Brazil } \\
\hline Anual growth rate of real GDP (\%) & 2,9 & 1,6 & 3,1 & 5,2 & $-0,3$ & 7,5 & 2,7 & 2,5 \\
\hline $\begin{array}{l}\text { Anual growth rate of real } \\
\text { importations (\%) }\end{array}$ & $-2,9$ & 10,6 & 14,1 & 17,6 & $-17,5$ & 38,2 & 8,9 & 3,0 \\
\hline $\begin{array}{c}\text { Anual growth rate of real } \\
\text { exportations (\%) }\end{array}$ & 8,7 & 5,0 & 8,8 & $-2,5$ & $-10,8$ & 9,5 & 2,9 & 2,7 \\
\hline Current Account/GDP (\%) & $-3,0$ & $-1,7$ & $-0,5$ & $-1,7$ & $-1,5$ & $-2,2$ & $-2,1$ & $-3,2$ \\
\hline Gross Public Debt/GDP (\%) & n.a. & n.a. & n.a. & 63,5 & 66,9 & 65,2 & 66,2 & 65,1 \\
\hline
\end{tabular}

Source: International Monetary Fund (IMF) WEO April 2012 and update July 2012, n.a. not available, 1) Forecast (2012). 
The global financial crisis led all over the world to expressive and new monetary and fiscal countermeasures to save the world from a new Great Depression as in the decade of 1930. Quantitative and qualitative easing by the central banks, recapitalization and nationalization of institutions of the financial system by the state (Fanny Mae e Freddy Mac and AIG in the United States, Northern Rock in Great Britain, the most important banks in Ireland and Iceland, Hypo Real in Germany) (SACHVERSTÄNDIGENRAT ZUR BEGUTACHTUNG DER GESAMTWIRTSCHAFTLICHEN ENTWICKLUNG, 2011). But these expansionary monetary and fiscal policies, which helped many countries to return to financial stability and growth in 2010, had a price. The balance sheets of many of the Central Banks of the mature economies of the world are full of risky assets, bought to save the financial system, and the prolonged monetary easing could lead to increasing inflation in the mature economies in the future and to currency wars in the future. But the greater problem seems to be the expressive growth of public debt and fiscal deficit in a lot of mature economies, created by Keynesian measures to save the world from a new depression and transferring private debt to public debt or public risk (by emergency measures of central banks and central government). But in the aftermath of an unsustainable expansion fuelled by credit growth and more leveraging by the private sector the problem after the crisis is now the deleveraging of the private and the public sector. The BIS 81st Annual Report of 2011 shows the problems ahead:

Crisis-related expansions of sovereign debt have worsened what were already unsustainable fiscal policy trajectories, and private sector debt remains too high. The result is that, today, policymakers and households have virtually no room for manoeuvre. All financial crises, especially those generated by a credit-fuelled property price boom, leave long-lasting wreckage. But we must guard against policies that would slow the inevitable adjustment. The sooner that advanced economies abandon the leverage-led growth that precipitated the Great Recession, the sooner they will shed the destabilising debt accumulated during the last decade and return to sustainable growth. The time for public and private consolidation is now. (BIS, 2011, p.10).

But the severity of euro area sovereign debt crisis led international institution, like the BIS, the OECD and the IMF to more prudent positions for deleveraging appointing for the risk that fiscal contractions could lead the world economy again into recession. For example, the director of the IMF, Lagarde (2012), warns that fiscal consolidation must be done sensibly, not to harm growth and political and social stability and to prevent a deflationary spiral. The prolonged monetary expansion could also lead to an acceleration of inflation in mature economies in the future and could be seen as a form of currency war (as the finance minister of Bra- 
zil Mantega (BRASIL..., 2012) evaluates the policy) to depreciate currencies in mature countries, gaining competitive advantage and hurting the Brazilian industry.

To counter the soaring bond yields of Portugal, Italy, Ireland, Greece and Spain the European Central Bank (ECB) introduced in September 2012 Outright Monetary Transactions (EUROPEAN CENTRAL BANK, 2012) (OMTs) facilitating the buying of short term sovereign debt (maturity between one and three years) without specified limits to bring down yields on sovereign debt and relieve the pressure on the nations with fiscal problems in the euro area.

Table 2 shows the macroeconomic fundamentals for the countries in the euro area which are in the centre of the turmoil of de euro area sovereign debt crisis. The table shows that all countries in the centre of the crisis (Portugal, Ireland, Italy, Greece and Spain) suffered deep recessions in the global financial crisis of 2008/09 leading to higher fiscal deficits and fast growing public debt (in relation to GDP). Obviously Greece and Portugal had not sustainable current account deficits and fiscal deficits in the whole decade of 2000, but Spain and Ireland were fiscally stable before the crisis and the bursting of the local housing bubble and a deep banking crisis led to deep fiscal deficits and fast growing public debt, accompanied by a deepening recession, led to the problems since may of 2010 .

Obviously the crisis of sovereign debt is also a crisis of European financial institutions with expressive assets of these sovereign bonds. A banking crisis is interrelated with the euro area sovereign debt crisis and the emergency programs of the European Union and the IMF are focused on the countries in crisis but also on the financial stability of the European banking system. In 2011 and 2012 the European Central Bank (ECB) was following the Federal Reserve in expressive monetary easing and intervention in the secondary sovereign debt markets, but the financial systems in some of the countries in crisis are yet shaky in summer of 2012 and the countries are in recessions.

Table 2 shows that all PIIGS countries experienced deep recessions in 2009, while in Greece the recession is also worsening in 2010 and 2011. It shows also that the current account deficits (especially in Greece and Portugal) were and are unsustainable especially when accompanied by fiscal deficits (expressive in Ireland caused by the salvation by the state of the national financial system (-32\% in 2010) and in Greece) which led to accelerating growth of the coefficient public debt/ GDP, unsustainable especially for Greece, even after the default.

While the euro area sovereign debt crisis yet doesn't show expressive contagion to the world economy, previsions of international organizations for the global and national growth in 2012 were corrected downwards as the crisis turned worse at the end of 2012. The impacts of the global instability were also felt in Brazil, were national previsions for growth in 2012 were also corrected downwards and the 
government reduced taxes on consumption and the central bank of Brazil reduced the basic interest rate SELIC.

Table 2 - Macroeconomic perspectives for the countries in the center of the euro area crisis 2000-2012

\begin{tabular}{|c|c|c|c|c|c|c|c|c|}
\hline & 2000-05 & 2006 & 2007 & 2008 & 2009 & 2010 & 2011 & 2012 \\
\hline Growth rate of GDP (\%) & & & & & & & & Forecast \\
\hline European Union (EU) & 1,9 & 3,3 & 3,0 & 0,4 & $-4,3$ & 1,9 & 1,5 & $-0,3$ \\
\hline Portugal & 1,4 & 1,4 & 2,4 & 0,0 & $-2,9$ & 1,4 & $-1,6$ & $-3,2$ \\
\hline Irland & 5,7 & 5,3 & 5,2 & $-3,0$ & $-7,0$ & $-0,4$ & 0,7 & 0,6 \\
\hline Italy & 1,4 & 2,2 & 1,7 & $-1,2$ & $-5,5$ & 1,8 & 0,4 & $-1,7$ \\
\hline Greece & 4,0 & 5,5 & 3,0 & $-0,2$ & $-3,3$ & $-3,5$ & $-6,9$ & $-5,3$ \\
\hline Spain & 3,6 & 4,1 & 3,5 & 0,9 & $-3,7$ & $-0,1$ & $-0,2$ & $-2,0$ \\
\hline \multicolumn{9}{|l|}{ Current Account/GDP (\%) } \\
\hline Portugal & $-9,0$ & $-10,7$ & $-10,1$ & $-12,6$ & $-10,9$ & $-9,9$ & $-8,0$ & $-3,8$ \\
\hline Irland & $-1,0$ & $-3,5$ & $-5,3$ & $-5,7$ & $-2,9$ & 0,5 & 0,5 & 1,7 \\
\hline Italy & $-0,9$ & $-2,6$ & $-2,4$ & $-2,9$ & $-2,1$ & $-3,5$ & $-3,6$ & $-2,6$ \\
\hline Greece & $-6,9$ & $-11,2$ & $-14,4$ & $-14,7$ & $-11,0$ & $-10,1$ & $-8,6$ & $-6,3$ \\
\hline Spain & $-4,5$ & $-9,0$ & $-10,0$ & $-9,6$ & $-5,2$ & $-4,6$ & $-4,0$ & $-2,3$ \\
\hline \multicolumn{9}{|l|}{ Fiscal deficit/GDP (\%) } \\
\hline Portugal & $-3,7$ & $-4,1$ & $-3,1$ & $-3,6$ & $-10,2$ & $-9,8$ & $-5,9$ & $-4,5$ \\
\hline Irland & 1,5 & 2,9 & 0,1 & $-7,3$ & $-14,0$ & $-31,3$ & $-10,3$ & $-8,7$ \\
\hline Italy & $-3,1$ & $-3,4$ & $-1,6$ & $-2,7$ & $-5,4$ & $-4,5$ & $-3,6$ & $-1,6$ \\
\hline Greece & $-5,2$ & $-5,7$ & $-6,5$ & $-9,8$ & $-15,6$ & $-10,8$ & $-9,0$ & $-7,0$ \\
\hline Spain & $-0,1$ & 2,4 & 1,9 & $-4,5$ & $-11,2$ & $-9,3$ & $-6,2$ & $-4,4$ \\
\hline \multicolumn{9}{|l|}{ Gross Public Debt/GDP (\%) } \\
\hline Portugal & 55,0 & 63,9 & 68,3 & 71,6 & 83,0 & 92,9 & 106,0 & 121,9 \\
\hline Irland & 32,2 & 24,7 & 24,9 & 44,4 & 65,2 & 94,9 & 109,3 & 118,8 \\
\hline Italy & 106,3 & 106,6 & 103,6 & 106,3 & 116,1 & 119,0 & 121,1 & 128,1 \\
\hline Greece & 100,8 & 106,1 & 105,4 & 110,7 & 127,1 & 142,8 & 165,6 & 168,0 \\
\hline Spain & 50,9 & 39,6 & 36,1 & 39,8 & 53,3 & 60,1 & 75,3 & 87,9 \\
\hline $\begin{array}{l}\text { Effective interest rate on } \\
\text { public debt bonds (\%) }\end{array}$ & $\begin{array}{l}\mathrm{dez} / 00- \\
05\end{array}$ & $\operatorname{dez} / 06$ & $\operatorname{dez} / 07$ & dez/08 & dez/09 & $\mathrm{dez} / 10$ & dez/11 & 2012 \\
\hline Portugal & 4,37 & 3,96 & 4,47 & 4,00 & 3,91 & 6,53 & 13,08 & 12,08 \\
\hline Irland & 4,31 & 3,76 & 4,45 & 4,57 & 4,88 & 8,45 & 9,4 & 7,35 \\
\hline Italy & 5,60 & 4,04 & 4,54 & 4,47 & 4,01 & 4,60 & 6,81 & 6,45 \\
\hline Greece & 4,32 & 4,04 & 4,53 & 5,08 & 5,49 & 12,01 & 21,14 & 22,40 \\
\hline Spain & 4,28 & 3,82 & 4,35 & 3,86 & 3,81 & 5,38 & 5,53 & 5,86 \\
\hline
\end{tabular}

Source: Eurostat, IMF - WEO and Fiscal Monitor 9/2011, OECD World Economic Outlook 4/2012.

Referring to the impacts of the global financial crisis 2008/09, Cintra e Prates (2011, p. 26, translation of the author) show the channels of transmission of an international crisis to Brazil, focusing on the exchange rate and on the balance of payments (specially on exports, flows of capital and prices of commodities): 
i) the retraction of portfolio investments in the context of risk aversion e preference for liquidity; ii) a reduction and, after the failure of Lehman Brothers, the interruption of external credit (credits, bonds, commercial papers etc.), including those (credits) directed to external trade; iii) the reduction of direct external investment as result of de-acceleration of growth in the mature economies; iv) the reduction of demand of the mature economies and the fall of commodity prices; iv) the rise of remittance of profits of the branches of transnational companies and foreign banks; v) the reduction of unilateral transfers of immigrants. (CINTRA; PRATES, 2011, p. 26, translation of the author).

They also mention the deterioration of expectations of Brazilian economic agents as consequence of crisis and the prevision of contraction of global demand as a factor influencing negatively the economic activity in Brazil.

The impacts for the Brazilian economy depend on the direct consequences on trade flows and capital flows of Brazil with the European Union, but also on the indirect impacts of the crisis for Brazil by the impacts the crisis has on important global economies like the United States, China, Japan and other countries. This depends partially on trade and capital flows between the European Union and its partners in trade and capital flows. But, in first place, there exists uncertainty of the impacts that the crisis in countries of minor economic importance like Greece, Portugal and Ireland could mean for Spain and Italy and with these countries for the contagion to the European Union and the global economy. There is also uncertainty to what extent the political and economic measures of the European Commission could stabilize the economic situation and the euro in the future. The political future of the stability measures of the EU and the ECB and the future of the euro for the countries in crisis is also uncertain, because of the political difficulties created by the problems to convince the national voters of the necessity to bail out these countries, driving healthy economies of the euro area deeper in debt and making austerity policies necessary for them in the near future. In the countries in crisis the austerity measures accompanying the salvation measures of the EU and the International Monetary Fund (IMF) are turning these countries economically, politically and socially unstable. The Outright Monetary Transactions by the ECB (EUROPEAN CENTRAL BANK, 2012) (OMTs) facilitating the buying of short term sovereign debt (maturity between one and three years) without specified limits to bring down yields on sovereign debt and relieve the pressure on the nations with fiscal problems in the euro area are a policy which avoids some of the political problems, but creates expectations of rising inflation in the future. 


\section{The Impacts of the Crisis on International Trade and Transferences of Income to Brazil}

Chernavsky (2011, p. 81) mentions that the impact of a retraction of exports on the economic activity in Brazil depends on:

- The change of the exchange-rate (appreciation or depreciation);

-The change in volumes and/or prices of exportations;

- The multiplier effect (on domestic income);

- The participation of exportations in demand.

End of July of 2008 shows the exchange-rate with de US dollar appreciated in nominal as in real terms with 1,5658 R $\$ /$ US $\$$, the depreciation begins in September 2008 reaching its highest value end of February 2009 with 2,3776 R $\$ / U S \$$ (BCB, monthly dates end of month), a depreciation of nearly $52 \%$, afterwards the real begins to appreciate (end of December 2009 1,7404 R $\$ / U S \$$ ). The depreciation of the real reduced the effect of the fall of Brazilian exportations in 2009 on the domestic income. The euro area sovereign debt crisis may also lead to a fall in Brazilian exportations to the European Union, but the depreciation to the euro might be less than in the 2008/09 crisis to the dollar, because the euro might depreciate in international context when the crisis worsens. Brazilian government and the Brazilian Central Bank are taking measures in the spring of 2012 to depreciate the real smoothly to gain competiveness and the real depreciates smoothly against US dollar and euro.

Table 3 shows the consequences of the crisis by comparing Brazilian exportations by product groups of 2009 with respect to 2009. It shows a general retraction in value in dollars of $22,7 \%$. An international crisis normally leads to a reduction of international trade as a consequence of falling global demand. 
Table 3 - Brazilian Exportations by product groups 2009/08 (with participation of more than $1 \%$ ), value in millions US $\$$ fob, kilogram e medium price/t, classified by expression of exportations in 2009

\begin{tabular}{|c|c|c|c|c|c|c|c|}
\hline & 2009 & $\%$ & 2008 & $\%$ & $\begin{array}{c}\text { Variation } \\
2009 / 2008 \\
\text { in value } \%\end{array}$ & $\begin{array}{c}\text { Variation } \\
2009 / 2008 \\
\text { in volume } \\
\%\end{array}$ & $\begin{array}{c}\text { Variation } \\
2009 / 2008 \\
\text { in price } \%\end{array}$ \\
\hline TOTAL & 152.995 & 100,0 & 197.942 & 100,0 & $-22,71$ & $-2,88$ & * \\
\hline Soy & 17.251 & 11,3 & 17.986 & 9,1 & $-4,09$ & 8,45 & $-11,57$ \\
\hline $\begin{array}{c}\text { Transport } \\
\text { Material }\end{array}$ & 16.160 & 10,6 & 27.026 & 13,7 & $-40,21$ & $-42,08$ & 3,23 \\
\hline Oil & 14.947 & 9,8 & 23.047 & 11,6 & $-35,15$ & 9,75 & $-40,91$ \\
\hline $\begin{array}{c}\text { Minerals } \\
\text { (iron ore ....) }\end{array}$ & 14.453 & 9,5 & 18.727 & 9,5 & $-22,82$ & $-6,64$ & $-17,33$ \\
\hline Meat & 11.471 & 7,5 & 14.283 & 7,2 & $-19,69$ & $-2,24$ & $-17,85$ \\
\hline $\begin{array}{l}\text { Metallurgic } \\
\text { Products }\end{array}$ & 11.104 & 7,3 & 19.427 & 9,8 & $-42,84$ & $-22,63$ & $-26,12$ \\
\hline $\begin{array}{l}\text { Chemic } \\
\text { Products }\end{array}$ & 10.877 & 7,1 & 12.225 & 6,2 & $-11,03$ & 14,29 & $-22,15$ \\
\hline $\begin{array}{c}\text { Sugar and } \\
\text { Alcohols }\end{array}$ & 9.716 & 6,4 & 7.873 & 4,0 & 23,41 & 14,31 & 7,96 \\
\hline Machines & 6.256 & 4,1 & 9.671 & 4,9 & $-35,31$ & $-42,95$ & 13,38 \\
\hline $\begin{array}{l}\text { Paper and } \\
\text { Cellulose }\end{array}$ & 5.001 & 3,3 & 5.834 & 3,0 & $-14,29$ & 15,27 & $-25,64$ \\
\hline $\begin{array}{c}\text { Electric } \\
\text { electr. } \\
\text { Products }\end{array}$ & 4.964 & 3,2 & 6.500 & 3,3 & $-23,64$ & $-28,72$ & 7,12 \\
\hline Coffee & 4.251 & 2,8 & 4.733 & 2,4 & $-10,17$ & 3,72 & $-13,39$ \\
\hline $\begin{array}{l}\text { Tobacco } \\
\text { and } \\
\text { cigarettes }\end{array}$ & 3.046 & 2,0 & 2.752 & 1,4 & 10,68 & $-2,44$ & 13,45 \\
\hline $\begin{array}{c}\text { Shoes and } \\
\text { leather }\end{array}$ & 2.764 & 1,8 & 4.064 & 2,1 & $-31,99$ & $-3,29$ & $-29,68$ \\
\hline $\begin{array}{c}\text { Textile } \\
\text { Products }\end{array}$ & 1.895 & 1,2 & 2.422 & 1,2 & $-21,76$ & $-12,76$ & $-10,31$ \\
\hline $\begin{array}{l}\text { Metals, } \\
\text { precious } \\
\text { stones }\end{array}$ & 1.737 & 1,1 & 1.544 & 0,8 & 12,44 & $-2,82$ & 15,7 \\
\hline Timber & 1.678 & 1,1 & 2.759 & 1,4 & $-39,17$ & $-30,64$ & $-12,3$ \\
\hline $\begin{array}{c}\text { Orange } \\
\text { juice }\end{array}$ & 1.619 & 1,1 & 1.997 & 1,0 & $-18,91$ & 0,74 & $-19,51$ \\
\hline
\end{tabular}

Source: Brasil, Ministério do Desenvolvimento, Indústria e Comércio Exterior.

A fall in volumes affects directly domestic production, income and demand, while a fall of prices affect the economy only indirectly (CHERNAVSKY, 2011, p. 82) and the effect may be accommodated by depreciation of the exchange-rate. Referring to estimates of the WTO, Castilho (2011, p. 100) mentions a reduction in 
international trade in 2009 of $12,8 \%$ in volume and $23 \%$ in value. Some commodity prices crashed after September 2009 but the level of many commodity prices was at a 30 years high (OECD-FAO, 2010). The Brazilian exportations showed a reduction of 22,7\% in value in 2009 (BRASIL, 1012). Generally prices for Brazilian exportations were falling more than volumes, especially for commodities (Soy (P: $-11,6 \%$; $\mathrm{V}:+8,5 \%)$, oil (P: $-40,9 \%$; $\mathrm{V}:+9,8 \%$ ), iron ore (P: $-15,2 \%$; $\mathrm{V}:-5,6 \%)$, meat (P:$-17,9 \%$; V: $-2,2 \%$ ), sugar (P: +8,0\%; V: +14,3\%), coffee (P: -13,4\%; V: + 3,7\%) (BRASIL, 2012). But for industrial products volumes were also falling rapidly in 2009 (for example: Transport materials -42\%; Machines - 43\%; Electric materials -29\%), all dates from the Ministry of Development, Industry and Foreign Trade (MDIC) and all of the products reported represent more than 1\% of exportations in 2009. The euro area sovereign crisis might with falling demand also influence negatively Brazilian exportations to the European Union, but in the last years Brazil was reaching a diversification of trade partners, especially in Asia, Russia and the Medium Orient, so the effect of the new crisis could be less, if the crisis didn't turn worse.

The multiplier effect of exportations, in this case a negative effect of a possible crisis in the euro area, depends, as Chernavsky $(2011$, p. 82) considers on the intensity of labor in the exportation list of Brazil and the size of the multiplier depends on the importance of salaries in the production of tradable goods. Chernavsky considers that in the production of basic goods (about $50 \%$ of Brazilian exportations) labor is of inferior importance than in the mean of GDP, reducing the negative effect of the multiplier.

The participation of exportations in GDP is also relatively small for Brazil, while it was increasing in the 2000 decade to nearly $15 \%$ of GDP, decreasing in the crisis to 9,5\% (Banco Central do Brasil (BCB), Indicadores econômicos e Balanço de Pagamentos). Thus a decrease in demand for Brazilian product in a possible crisis does not have an effect as serious as in countries heavily dependent on exportations like Germany, South Korea or China.

The direct influence of a deterioration of the economic situation in the European Union on Brazilian exports of goods depends on the participation of exports of goods in Brazilian GDP (in 2010 9,71\%, from 2008 to 2009 experiencing a fall from $12,56 \%$ to $9,57 \%$ (BRASIL, 2012), and the participation of exportation to the European Union (2011) (21,4\% with minor expression of the countries with problems: Italy 2,1\%, Spain 1,9\%, Portugal 0,8\%, Greece 0,09\% and Ireland 0,09\%) (BRASIL, 2012). The main partners of international trade of Brazil are in 2010 Asia $27,9 \%$ (China 15,3\%), EU 21,4\%, ALADI 20,4\% (Mercosul 11,2\%); United States 9,6\% and the Median Orient 5,2\% (BRASIL, 2012). Obviously trade with the European Union is important for Brazil; an economic and political crisis could deteriorate exportations of Brazil to the EU. But without expressive contagion to the other important partners of Brazilian trade the shock will not be as serious as in the global financial 
crisis of 2008/09. The question of indirect effects is about the impacts of the crisis in the euro area for the imports of the EU from their trade partners, which might decline in crisis and transmit the effects of crisis to the trade partners. The share on EU importations reached its highest value in 1999 and 2003 with 19,5\% of world importations, declining in the crisis from $19,1 \%$ in 2008 to $18 \%$ in 2009 and $17,3 \%$ in 2010 (EUROSTAT, 2011, p. 14). The main partners for the importations of the European Union (extra-EU-trade) are: China 18,7\%, United States 11,3\%, Russia $10,6 \%$, Switzerland 5,5\%, Norway 5,3\%, Japan $4,4 \%$ and as extra-EU country rank 10 Brazil 2,2\%. The indirect effect of a crisis can reach Brazil by the negative effect of importation of the EU from China and the United States, important trade partners of Brazil.

Since the beginning of the euro area sovereign debt crisis in 2010, the Brazilian economy shows a sharp reduction of growth since the end of 2011 and in the first semester of 2012 is growing very slowly. The value of the total of Brazilian exportations in US dollar after the fall of $22,7 \%$ in 2009 shows growth of $32,0 \%$ in 2010 and of $26,8 \%$ in 2011, in the months to July of 2012 the Brazilian exportations are showing a decline of $-1,7 \%$ in value in relation to the same period in 2011 (BRASIL, 2012). Between basic products the commodities of iron ore declined $-20 \%$ in value (nearly all of the decline reflecting declining prices, reflecting the slowdown of the global economy) in the months to July of 2012 and coffee $-22,3 \%(20,2 \%$ reflecting declining quantities exported), but other commodities like soy showed growth of $33,2 \%$ in value $(25,9 \%$ in quantity) (BRASIL, 2012). Between the semi manufactured products sugar showed a decline of $-20,7 \%$ (-18,3\% in quantity), between the manufactured products refined sugar showed a decline of $-26,7 \%$ in value $(-23,7 \%$ in quantity) (BRASIL, 2012). This could be reflecting the slowdown of the global economy, but the effect is less than in the Great recession of 2008/09.

But the almost stagnating Brazilian economy in 2012 could have other causes than the European crisis, considering that the participation of the countries in crisis in the euro area in Brazilian exportations is limited. The participation of these countries in all those countries fell from 2007 to 2011 , but the overall participation is low (Portugal from $1,12 \%$ to $0,8 \%$, Ireland from $0,22 \%$ to $0,12 \%$, Italy from $2,78 \%$ to $2,13 \%$, Greece from $0,23 \%$ to $0,07 \%$ and Spain from $2,12 \%$ to $1,82 \%$ ) (BRASIL, 2012).

The effect of a possible reduction of transferences of the labor force working in foreign countries is also sensible, but not extreme. The data on transferences in the crisis of 2008/09 show a sensible decline in inflows of $-23,6 \%$ (Decline of $-30,6 \%$ from the United States and -40,8\% from Japan, together responding for $86,1 \%$ of the inflows in 2000 , declining to $59,3 \%$ in 2009 and to $45,3 \%$ in 2011), but it is of minor importance (transferences are about $2 \%$ of the value of exportations of goods), 
as Table 4 shows. So a possible serious crisis in the euro area might be having some negative impacts on remittances but their overall importance is minor.

Table 4 - Flows of Remittances, Unilateral Transactions Brazil 2000-2011, US\$ Million

\begin{tabular}{ccccc}
\hline Year & $\begin{array}{c}\text { Liquid Inflow } \\
\text { Remittances } \\
\text { US\$ Million }\end{array}$ & $\begin{array}{c}\text { Inflow } \\
\text { Remittances } \\
\text { US\$ Million }\end{array}$ & $\begin{array}{c}\text { Outflow } \\
\text { Remittances } \\
\text { US\$ Million }\end{array}$ & $\begin{array}{c}\text { Inflow/ } \\
\text { Exportations of } \\
\text { Goods \% }\end{array}$ \\
\hline 2000 & 932,1 & 1112,3 & 180,2 & $2,0 \%$ \\
2001 & 1009,0 & 1178,5 & 169,5 & $2,0 \%$ \\
2002 & 1572,6 & 1711,0 & 138,4 & $2,8 \%$ \\
2003 & 1882,1 & 2018,1 & 135,9 & $2,8 \%$ \\
2004 & 2292,0 & 2458,7 & 166,7 & $2,5 \%$ \\
2005 & 2217,4 & 2479,9 & 262,5 & $2,1 \%$ \\
2006 & 2580,6 & 2889,8 & 309,2 & $2,1 \%$ \\
2007 & 2294,7 & 2808,8 & 514,1 & $1,7 \%$ \\
2008 & 2284,5 & 2912,6 & 628,1 & $1,5 \%$ \\
2009 & 1555,2 & 2223,8 & 668,6 & $1,5 \%$ \\
2010 & 1220,2 & 2075,6 & 855,4 & $1,0 \%$ \\
2011 & 1157,8 & 1969,2 & 811,5 & $0,8 \%$ \\
\hline
\end{tabular}

Source: BCB Séries Temporais.

The effect of a possible rise in remittances of profits from transnational companies and foreign banks shows Table 5. Interestingly the remittances in 2009 declined significantly with respect to 2008 for direct investments, probably because the profits of transnational companies decreased in the crisis. 
Table 5 - Income of Direct Investment, Portfolio Investment and other Investments Brazil 2000-2011, US\$ Million

\begin{tabular}{ccccccc}
\hline Year & Liquid Flow & Inflow & Outflow & $\begin{array}{c}\text { Interest } \\
\text { Credits } \\
\text { between } \\
\text { Companies } \\
\text { Liquid }\end{array}$ & $\begin{array}{c}\text { Income } \\
\text { Portfolio } \\
\text { Investment } \\
\text { Liquid }\end{array}$ & $\begin{array}{c}\text { Income } \\
\text { other } \\
\text { Investments } \\
\text { Liquid }\end{array}$ \\
\hline 2000 & -2.173 & 932 & -3.105 & -1.066 & -8.545 & -6.181 \\
2001 & -3.438 & 264 & -3.702 & -1.201 & -9.621 & -5.579 \\
2002 & -4.034 & 857 & -4.891 & -949 & -8.384 & -4.925 \\
2003 & -4.076 & 760 & -4.836 & -1.022 & -8.743 & -4.820 \\
2004 & -4.937 & 916 & -5.853 & -852 & -10.415 & -4.497 \\
2005 & -9.142 & 641 & -9.783 & -1.161 & -11.778 & -4.101 \\
2006 & -11.445 & 928 & -12.373 & -1.381 & -11.028 & -3.803 \\
2007 & -16.745 & 1.152 & -17.898 & -744 & -7.065 & -5.185 \\
2008 & -25.348 & 1.526 & -26.874 & -1.427 & -8.039 & -6.293 \\
2009 & -17.765 & 1.186 & -18.951 & -1.977 & -9.213 & -5.332 \\
2010 & -23.591 & 888 & -24.479 & -1.913 & -9.964 & -4.517 \\
2011 & -27.379 & 1.804 & -29.183 & -2.252 & -12.164 & -6.091 \\
\hline
\end{tabular}

Source: BCB Séries Temporais.

So a significant influence of a serious euro area crisis in current account should be expected only in the exportations of Brazilian goods.

\section{The Impacts of the Crisis on Expectations for Brazil}

The rational expectations hypothesis and the efficient markets hypothesis are generally assumed in economic theory and in econometric models based of dynamic stochastic general equilibrium (DSGE) models. In theory rational expectations are contested, for instance, by Kirman (2010, p. 511) because in economic and econometric modeling they are represented as homogenous by the hypothesis of the representative agent and the agents are isolated and only linked through the anonymous market. Obviously in normal times the expectations of agents are heterogeneous and the agents are interacting, small changes in the micro level therefore could lead to major changes in the macro level. But also the occurrence of financial, currency and economic crises in the late XX century and the beginning of the XXI century contested the validity of theses dominant hypothesis (GOMES, 2011, p. 47). Reinhart and Rogoff (2008) argue that the recent financial crisis is similar to a long chain of crises in developed and developing countries, and that "financial markets, particularly ones reliant on leverage..., can be quite fragile and subject to crises of confidence". And Kindleberger and Aliber (2011) show that international financial crises are not a "black swan", as Taleb (2008) assumes, but a quite normal occurrence in capitalist economies since centuries. Why are expec- 
tations of economic agents changing totally in a moment from euphoria to panic, as in the moment of failure of Lehman Brothers on September, 15? Why the memory of serious crises in the past didn't warn economic agents of the coming crisis? Reinhart and Rogoff (2008) argue that the last question could be answered in four words: This time is different. They explain that this syndrome is

[...] rooted in the firmly held belief that financial crises are things that happen to other people in other countries at other times; crises do not happen to us, here and now. We are doing things better, we are smarter, we have learned from past mistakes. The old rules of valuation no longer apply. Unfortunately, a highly leveraged economy can unwittingly be sitting with its back at the edge of a financial cliff for many years before chance and circumstance provoke a crisis of confidence that pushes it off. (REINHART; ROGOFF, 2008, p. 1).

A second question is why the contagion to other countries is rapidly changing expectations, for instance, in the case of Brazil? Obviously globalization leads to increasing interdependence of markets and countries by international trade and capital flows. Gomes (2011, p. 48) shows that the climate of economic optimism in the first semester of 2008 was followed by a climate of pessimism and panic after the failure of Lehman Brothers, although the Brazilian financial system was not engaged in toxic assets emitted by the financial system of the United States. But there was uncertainness about the leverage of the national financial system and especially about speculative involvement of Brazilian firms (Aracruz, Sadia, Votorantim) in the derivate market, which led to heavy losses for these firms. But in March 2009 the expectations of Brazilian markets were already bettering.

Obviously the sovereign debt crisis in the euro area led to a reversion of optimism in the Brazilian markets in the second semester of 2011 and in the beginning of 2012 the Brazilian economy is showing signs of stagnation. While financial markets in the world remained calm after the default of Greece in March 2012, the situation could worsen if the crisis spreads to other countries in the euro area, especially Spain and Italy, and the political crisis in the area worsens because voters fear the consequences of monetary easing of the European Central bank and the costs of the rescue packets for the PIIGS countries and for the banking sector in the euro area. On the other side, Brazilian exportations are now more geographically diversified and the Brazilian financial system seems much more stable than the financial systems in the euro area and the United States. Also demand for food says strong in the global economy, helping Brazilian exportations. 


\section{The Impacts of the Crisis by Monetary Channels for Brazil and the Political Channel}

The main impacts in the monetary channels, shown in the capital account, may be a decline in direct investment, a decline in portfolio investment to Brazil and a decline of credits for Brazilian exporting companies.

As Table 6 shows direct foreign investment as a total suffered a fall of $-30,6 \%$ in 2009 with respect to 2008 , but growth of $25,3 \%$ in respect of the mean 2001 to 2007. Probably foreign direct investment does reflect other causes than the crisis of 2008/09, for instance Germany and the United Kingdom show expressive positive growth rates of foreign direct investment to Brazil in 2009, while these countries were hit very hard by the crisis.

Table 6 - Direct Foreign Investment to Brazil, stocks 1995, 2000 and estimate for 2009, flows of ID mean 2001-07, 2008 and 2009 in Million US Dollars, classified by stock

estimate

\begin{tabular}{|c|c|c|c|c|c|c|c|c|}
\hline Country & $\begin{array}{c}\text { Stock DI } \\
1995\end{array}$ & $\begin{array}{c}\text { Stock DI } \\
2000\end{array}$ & $\begin{array}{c}\text { EstimateI } \\
\text { Stock ID } \\
2009\end{array}$ & $\begin{array}{c}\text { Mean } \\
\text { Inflow } \\
2001- \\
2009\end{array}$ & $\begin{array}{c}\text { Inflow } \\
2008\end{array}$ & $\begin{array}{c}\text { Inflow } \\
2009\end{array}$ & $\begin{array}{c}\text { Growth } \\
\text { Rate } \\
2008 / 09\end{array}$ & $\begin{array}{c}\text { Growth } \\
\text { Rate } 2009 \\
\text { to Mean } \\
2001 / 08\end{array}$ \\
\hline United States & $10.852,18$ & $24.500,11$ & $64.853,51$ & $4.079,59$ & $6.917,95$ & $4.878,32$ & $-29,5 \%$ & $10,0 \%$ \\
\hline Netherlands & $1.545,80$ & $11.055,33$ & $50.633,84$ & $4.176,15$ & $4.623,68$ & $5.721,78$ & $23,7 \%$ & $35,2 \%$ \\
\hline Spain & 251,01 & $12.253,09$ & $29.472,32$ & $1.430,94$ & $3.787,47$ & $3.415,19$ & $-9,8 \%$ & $97,9 \%$ \\
\hline France & $2.031,46$ & $6.930,85$ & $20.379,74$ & $1.208,04$ & $2.856,13$ & $2.136,48$ & $-25,2 \%$ & $51,1 \%$ \\
\hline $\begin{array}{l}\text { Cayman } \\
\text { Islands }\end{array}$ & 891,68 & $6.224,81$ & $20.269,39$ & $1.628,28$ & $1.554,67$ & $1.091,97$ & $-29,8 \%$ & $-32,6 \%$ \\
\hline Germany & $5.828,04$ & $5.110,24$ & $15.458,49$ & 978,92 & $1.036,57$ & $2.459,22$ & $137,2 \%$ & $149,4 \%$ \\
\hline Luxemburg & 408,05 & $1.034,11$ & $13.530,76$ & 860,37 & $5.937,32$ & 536,77 & $-91,0 \%$ & $-64,1 \%$ \\
\hline Japan & $2.658,52$ & $2.468,16$ & $13.073,32$ & 690,54 & $4.098,78$ & $1.672,57$ & $-59,2 \%$ & $49,8 \%$ \\
\hline Canada & $1.818,98$ & $2.028,30$ & $10.516,67$ & 811,28 & $1.438,02$ & $1.371,41$ & $-4,6 \%$ & $54,2 \%$ \\
\hline Portugal & 106,61 & $4.512,10$ & $10.500,41$ & 655,06 & $1.025,91$ & 376,97 & $-63,3 \%$ & $-46,3 \%$ \\
\hline Bermudas & 853,07 & $1.940,05$ & $8.299,29$ & 708,75 & $1.038,06$ & 359,94 & $-65,3 \%$ & $-52,0 \%$ \\
\hline Switzerland & $2.815,30$ & $2.252,05$ & $7.454,40$ & 580,06 & 772,86 & 369,07 & $-52,2 \%$ & $-38,9 \%$ \\
\hline $\begin{array}{l}\text { United } \\
\text { Kingdom }\end{array}$ & $1.862,61$ & $1.487,95$ & $6.126,28$ & 424,60 & 641,00 & $1.025,17$ & $59,9 \%$ & $127,0 \%$ \\
\hline $\begin{array}{l}\text { Virgens } \\
\text { Islands }\end{array}$ & 901,22 & $3.196,58$ & $5.975,12$ & 394,15 & 10,17 & 9,31 & $-8,4 \%$ & $-97,3 \%$ \\
\hline Italy & $1.258,56$ & $2.507,17$ & $5.426,93$ & 339,83 & 326,27 & 214,69 & $-34,2 \%$ & $-36,5 \%$ \\
\hline $\begin{array}{c}\text { Other } \\
\text { Countries }\end{array}$ & $7.612,54$ & $15.513,62$ & $45.819,49$ & $2.525,61$ & $7.821,46$ & $4.805,11$ & $-38,6 \%$ & $50,7 \%$ \\
\hline Total & $41.695,62$ & $103.014,51$ & $327.789,96$ & $21.492,17$ & $43.886,30$ & $30.443,97$ & $-30,6 \%$ & $25,3 \%$ \\
\hline
\end{tabular}

Source: BCB Séries Temporais, own calculations, 1) it's only a rough estimate, because it doesn't resume the outflows in the period from 2001 to 2009. 
Spain, Portugal and Italy are between the fifteen most important foreign direct investors to Brazil, as Table 6 shows (the countries classified by a rough estimate of stock of foreign investments in 2009, rough, because outflows are not represented in this estimate). The other PIIGS countries Ireland and Greece are of less importance for DI flows to Brazil (Mean 2001 to 2007 Ireland US\$ 40 Million (negative of Growth in $2009-81,7 \%$ ), Greece US\$ 2,4 Million (with an expressive growth rate in $2009282 \%$, but on a very small basis of the mean of 2001 to 2007). While Portugal and Italy shows expressive negative growth rates to 2008 and to the mean of 2001 to 2007, Spain shows a fall in respect of $2008-9,8 \%$, but a significant rise in 2009 with respect to the mean inflows of 2001 to 2007.

Table 7 shows flows of foreign portfolio investment and other foreign investment (especially credits) to Brazil. The fall in inflows obviously is beginning in 2008 yet, the inflows of investment in Brazilian stocks resumes in 2009, in bonds only in 2010 and of other foreign investment in 2010, while the Commercial credit is only resuming in 2011 . Therefore the monthly data (accumulated for 12 months to minimize noise in the data) are analyzed in Figure 1.

Table 7 - Portfolio Investment and Credits to Brazil, 2000-2011, Million US\$

\begin{tabular}{ccccccccc}
\hline & $\begin{array}{c}\text { Foreign } \\
\text { Portfolio } \\
\text { Investment }\end{array}$ & Stocks & Bonds & $\begin{array}{c}\text { Other } \\
\text { Foreign } \\
\text { Investment }\end{array}$ & $\begin{array}{c}\text { Commercial } \\
\text { Credit }\end{array}$ & $\begin{array}{c}\text { Credit } \\
\text { and } \\
\text { Finance }\end{array}$ & $\begin{array}{c}\text { Monetary } \\
\text { Authority }\end{array}$ & $\begin{array}{c}\text { Other } \\
\text { sectors }\end{array}$ \\
\hline 2000 & 8.651 & 3.076 & 5.575 & -15.213 & -6.409 & -8.774 & -10.434 & 1.660 \\
2001 & 872 & 2.481 & -1.609 & 9.353 & 4.233 & 5.714 & 6.639 & -925 \\
2002 & -4.797 & 1.981 & -6.778 & 2.150 & 1.741 & 1.031 & 11.363 & -10.332 \\
2003 & 5.129 & 2.973 & 2.156 & -686 & 236 & -1.549 & 4.645 & -6.194 \\
2004 & -3.996 & 2.081 & -6.076 & -8.721 & 1.181 & -10.421 & -4.494 & -5.927 \\
2005 & 6.655 & 6.451 & 204 & -22.486 & 3.585 & -26.753 & -23.402 & -3.351 \\
2006 & 9.076 & 7.716 & 1.360 & 24.104 & 12.789 & 9.851 & -138 & 9.990 \\
2007 & 48.104 & 26.217 & 21.887 & 31.683 & 17.371 & 13.694 & -138 & 13.832 \\
2008 & -767 & -7.565 & 6.798 & 8.143 & 4.462 & 5.172 & 0 & 5.172 \\
2009 & 46.159 & 37.071 & 9.087 & 14.076 & 4.100 & 4.926 & 0 & 4.926 \\
2010 & 67.795 & 37.684 & 30.111 & 41.415 & -713 & 41.160 & -4 & 41.163 \\
2011 & 17.474 & 6.198 & 11.276 & 49.139 & 22.089 & 30.197 & 0 & 30.197 \\
\hline
\end{tabular}

Source: BCB Séries Temporais.

Figure 1 shows the accumulated (for 12 months) flows of portfolio and other investments to Brazil from December 2005 to January 2012. The fall of the components of foreign investment in stocks and bonds and commercial credit and other credit begins with the sharpening of the global crisis of 2008/09 in September of 2008 , recovering in the end of 2009 , but commercial credits only fully recovering in the spring of 2011. The fall in foreign investment in stocks is reflected in the fall of 50\% of the Brazilian stock market index IBOVESPA beginning in May 2008 and recovering slowly in 2009. 
Figure 1 - Foreign Portfolio Investment -FPI (Stocks and Bonds) and Other Foreign Investments - OFI (Commercial Credit and other Credits) to Brazil accumulated for 12 months, December 2005-January 2012

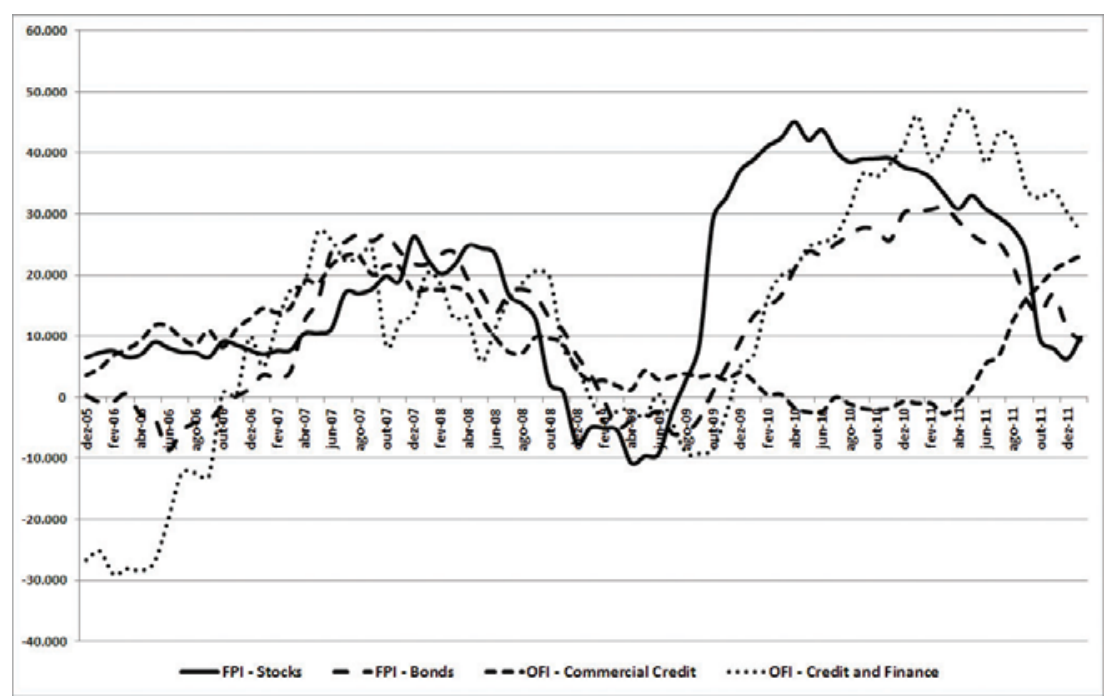

Source: BCB.

There could be a similar development if the European crisis is deepening but Brazil is now in better conditions to confront the problems with the experience in $2008 / 09$, especially in facing a possible credit crunch with easing monetary policy and credit by the national development bank BNDES and the public banks, Banco do Brasil and Caixa Econômica Federal.

It is important to realize that the prolonged expansionary monetary policies in the mature economies after the global crisis of 2008/09, which are yet used to stimulate the stagnating economies, could have impacts on future inflation. As well, calling it the political channel of contagion of crises, these policies could have political implications for a turn to more protectionist policies for a lot of countries. Prolonged expansionary monetary policies tend to have consequences on the exchange rate of the countries using these monetary policies, depreciating their exchange rates, which will hurt countries like Brazil for their exportations. Prolonged expansionary monetary policies on the other side implicate very low interest rates in the mature industrial countries, leading to inflows of capital to countries like Brazil with yet relatively high interest rates, appreciating the real yet more and hurting much more the Brazilian exportations. Political implications could be the application more protectionist policies for Brazil.

\section{Final Considerations}

To resume, the most likely outcome of the prevailing euro area sovereign debt crisis on the Brazilian economy should be less serious than the effects of the global financial crisis 2008/09, because Brazilian exportations are more diversified geographically and the demand for commodities should be stable, if the emerging 
markets in Asia are growing expressively as in the past decade and billions of new middle class consumers enter the global markets for food and other commodities. Brazilian financial markets and banks are more stable than their counterparties in the mature economies, thanks to regulation, and could now better confront a possible new credit crunch from the mature economies. Problems could arise if direct foreign and portfolio investment falls expressively, but other trade partners, like China, are also beginning to expand direct investments in Brazil. So the effects of the euro area sovereign debt crisis on the Brazilian economy should be less than the impacts of the global financial crisis 2008/09, if the European Union and the International Monetary Fund are able to avoid contagion of the crisis to the most important economies in the European Union and the world. But the long run problems of the global economy are yet present and present threats for the future of the global and the Brazilian economy: the global imbalances between countries with expressive positive current account (like China, Japan and Germany) and countries with expressive deficits in the current account and great global debtors (like the United States), the ongoing monetary easing in the United States and the euro area with unknown consequences in the future and the failure to initiate a process of deleveraging of the private and the public sector in the majority of the mature economies.

\section{References}

BANCO CENTRAL DO BRASIL. Séries Temporais. Available in: <www.bcb.gov.br>. Access in: Mar. 10, 2012.

BANK FOR INTERNATIONAL SETTLEMENTS - BIS. 81st Annual Report. Basel, 26 June 2011. Available in: <www.bis.org > . Access in: Mar. 2, 2012.

BRASIL pode taxar capital estrangeiro em 'guerra cambial', afirma Mantega. G1 Economia, 21 set. 2012. Available in: <http://g1.globo.com/economia/noticia/2012/09/brasil-pode-taxar-capital-estrangeiro-em-guerra-cambial-mantega-2.html> . Access in: Dec. 26, 2012.

BRASIL. Ministério do Desenvolvimento, Indústria e Comércio Exterior. Portal. Available in: <http://www.mdic.gov.br>. Access in: Mar. 18, 2012.

CASTILHO, M. Impactos da crise econômica internacional sobre o comércio exterior brasileiro. In: ACIOLY, L.; LEÃO, R. P. F. (Org.). Crise financeira global: mudanças estruturais e impactos sobre os emergentes e o Brasil. Brasília, DF: Ipea, 2011.

CHERNAVSKY, E. A transmissão da crise: incerteza, expectativas e comportamento convencional. In: ACIOLY, L.; LEÃO, R. P. F. (Org.). Crise financeira global: mudanças estruturais e impactos sobre os emergentes e o Brasil. Brasília, DF: Ipea, 2011.

CINTRA, M. A. M.; PRATES, D. M. Os países em desenvolvimento diante da crise financeira global. In: ACIOLY, L.; LEÃO, R. P. F. (Org.). Crise financeira global: mudanças estruturais e impactos sobre os emergentes e o Brasil. Brasília, DF: Ipea, 2011.

COMÉRCIO Exterior - Balança Comercial (different years). Available in: <http://www.mdic. gov.br>. Access in: Sept. 6, 2012. 
EUROPEAN CENTRAL BANK (ECB). Press release: technical features of outright monetary transactions. 2012, September 6. Available in: <http:/www.ecb.int/press/pr/date/2012/html/ pr120906_1.en.html >. Access in: Sept. 8, 2012.

EUROSTAT. External and Internal EU-trade: Yearbook 2011. Available in: <http://epp.eurostat.ec.europa.eu> Access in: Mar. 10, 2012.

Portal. Available in: <http://epp.eurostat.ec.europa.eu>. Access in: Mar. 12, 2012.

GOMES, K. R. A crise financeira e o comportamento do mercado brasileiro: entre euforia e incerteza. In: ACIOLY, L.; LEÃO, R. P. F. (Org.). Crise financeira global: mudanças estruturais e impactos sobre os emergentes e o Brasil. Brasília, DF: Ipea, 2011.

INTERNATIONAL MONETARY FUND. Financial stability report 10/2008: Financial stress and deleveraging. Macrofinancial Implications and Policy, Washington, DC. Available in: <www. imf.org >. Access in: Mar. 1, 2012.

. Fiscal Monitor, 9/2011. Available in: <www.imf.org >. Access in: Mar. 15, 2012.

2012.. World Economic Outlook, 9/2011. Available in: <www.imf.org > . Access in: Mar. 18,

KINDLEBERGER, C. P.; ALIBER, R. Z. Manias, panics, and crashes: a history of financial crises. Basingstoke: Palgrave, 2011.

KIRMAN, A. The economic crisis is a crisis for economic theory. CESifo Economic Studies, v. 56 (4), p.498-535, 2010.

LAGARDE, C. Anchoring stability to sustain higher and better growth. Zurich, May 7, 2012. Available in: <www.imf.org > . Access in: June 8, 2012.

MINSKY, H. P. Stabilizing an unstable economy. New York: McGrawHill, 2008.

OECD-FAO. Agricultural Outlook 2010-2019, 2010. Available in: <www.oecd.org>. Access in: Mar. 18, 2012.

REINHART, C. M.; ROGOFF, K. S. This time is different: eight centuries of financial folly. Princeton, NJ: Princeton University Press, 2009.

ROUBINI, N.; MIHM, S. A economia das crises: um curso relâmpago sobre o futuro do sistema financeiro internacional. Rio de Janeiro: Intrínseca, 2010.

SACHVERSTÄNDIGENRAT ZUR BEGUTACHTUNG DER GESAMTWIRTSCHAFTLICHEN ENTWICKLUNG. Jahresgutachten 2011/12: Verantwortung für Europa wahrnehmen. Available in: <www.sachverstaendigenrat.org > . Access in: Feb. 1, 2012.

TALEB, N. N. A lógica do cisne negro: o impacto do altamente improvável. Rio de Janeiro: BestSeller, 2008.

THE FINANCIAL CRISIS INQUIRY COMMISSION. The financial crisis inquiry report. New York: Public Affairs, 2011.

UNITED STATES GOVERNEMENT. Economic Report of the President 2012. Washington: Printing Office, 2012.

Recebido em: 21/01/2013.

Aceito em: 10/04/2013. 